\title{
Anne Jacobs, Alien Roots: A German Jewish Girlhood: From Belonging to
}

Exile. Melbourne: Makor Jewish Community Library, 2006, 411 pp, numerous illus., A\$30.00. ISBN 1876733683.

\section{Reviewed by Marion Spies}

The book under discussion was published as part of the 'write your story program' in which memoirs of ordinary Jewish people are brought to the attention of the public; musings, which in the first place were meant for the children and grandchildren of the authors. Anne(marie) Meyer Jacobs (1918-1982), born in Hannover, Germany, living in Australia, mainly in Melbourne, from 1940 to 1982, put her memories of her German girlhood to paper in the 1960s. Her children took the initiative to get them published.

Anne grew up in a wealthy, secular Jewish family in Hannover, with a grandmother living close by, who had come from Australia to marry a German. This fact later on made it possible for Anne, her brother Klaus, her mother and her grandmother to emigrate, and they were reunited in Melbourne after the war. Mainly because of their father's long illness and only secondly because of political unrest, the children were sent to a boarding school in Britain, and Anne later went to a convent school in Belgium. Shortly before the war she rejoined her brother in London.

We can discern three narrative strands in the book: Anne's children (in the preface and epilogue), young Anne in Germany, Britain and Belgium from 1923 to 1937, middle-aged Anne in Australia. In the preface Anne's children interpret their mother's story as one of "displacement, loss and renewal". (3). For them, everything which had happened to their mother in Germany is "different" and, in a metaphorical sense, "indecipherable" (3). For Anne, her children represent Australian readers, for whom she sets out the alien ways of Germans before the Second World War.

In the book the word "alien" has a threefold meaning: First, in the title, it refers to an Australian reader's notions of pre-World War II Germany, which is alien to him due to its old world culture. Anne tries to decipher this alien-ness. Second, when Anne is about 12 years old, her parents ask a Jewish teacher to explain to her what Judaism is all about. Anne resignedly comments that this teacher's endeavours were quite useless, because the Jewish God and religion remained "alien" to her. This confession has wider, political, implications later on: Because Anne is convinced that she is different from other Jews (she is talking about Eastern European Jews), she and her family hesitate to leave the country until it is almost 
too late, thinking that Hitler's persecutions do not concern them. She never learns. She still holds the conviction that she is different when she is writing the book. One has to admit, though, there is nothing "Jewish" about this girlhood, apart from one remark by Anne that the Meyer family did not have a Nativity scene under the Christmas tree. Anne herself calls her Jewishness "incidental" (353). Third, the word "alien" is used by the British authorities, when Anne is trying to get a work permit and is regarded as "enemy alien" (271). In the book, Anne tries to show that over the decades she overcame the last kind of alienness and finally turned into an Australian; how she found the "renewal" she was craving for after the loss of her German identity.

One of Anne's goals is to explain alien Germany to Australian readers. She begins doing so right from the start. Although she is (supposedly) just five years old, she sounds like a high school student, an attitude which she keeps up for the rest of the book. This can for example be seen in her use of words, especially when she is contrasting then and now, Germany and Australia. For her, everything is "either black or white" (118), mainly black; thus, German words are "ugly" (31), the German script is "a horrifying collection of difficult scrolls and loops" (35). And she does not really explain much about Germany; the feelings of the people, for example, were and remain a mystery for her: "It is difficult to rationalise the irrational, the intangible..." (136). Her scant_understanding becomes particularly obvious when she recounts the bickerings within her own family and when she tries to explain the political situation in Germany in the 1920s and 1930s.

The Meyers' style of living was typical for the German Großbürgertum before the war: music lessons, "sadistic" (35) governesses, lavish entertainments, haute couture, going to Spas (in the style of Aharon Appelfeld's Badenheim 1939), "old world formality" (72) and fairly strict rules of behaviour for the children. It is here that 'Anne, the Australian' stresses difference most: Compared to the more relaxed Australian lifestyle of the 1960s, she brands what in fact was quite usual in German circles (even after WWII) as unnatural, overly restrictive, antiquated. Among those items were for example the Herrensalon and the Grand Piano, as well as the fact that children were not allowed to speak at the table unless spoken to and that children did not have dinner with their parents. What Anne has to say about German secondary schools is not particularly objective, either. She sounds very self-important when she writes about the education she and her brother got (or rather, did not get) in Germany. This is particularly so in case of her English lessons, although the reader slightly wonders how she can judge them, having repeatedly stressed that throughout their childhood she and Klaus stubbornly refused to learn one word of English from their English-speaking relatives. For Anne, the supposed shortcomings of German school curricula have more serious 
consequences as well: She blames the gullibility of Germans to Hitler's ravings on their lack of political education.

Neither in the preface nor in interspersed comments on her later years in Britain and Australia do we learn much about Anne's relationship to her own children, only that she seems to have been a very easy-going mother. Here again, she stresses the contrast to her relationship with her own mother. However, it must have been a tortured one; throughout the book, Anne's pronouncements make it hard to decide whether Anne or her mother Margaret is more bitchy. Remarks such as: "My mother had no understanding of children and - unlike my father - no fondness for this section of humanity" (29), "... her total refusal or inability to praise or compliment me in any way" (30) are balanced by self criticism: "[I] was self-willed, bossy and thoroughly unlikeable" (36), "nicely negative and antisocial" (197). Klaus is seen as a shy, taciturn boy who suffers intensely from the pranks of his school fellows. Grandma Alice, 'the Australian' is sketched as an independent, self-willed outsider. Excepting Anne, it is only her father who appears as a round character, and Anne totally adores him. Therefore, many little incidents and everything he did for his children are lovingly put to paper. Obviously, his daughter still bemoans his short life (his painful death is recounted in detail), and by writing about him wants to make sure that she does not forget one single instance; neither his love of flowers nor his delight in good food. It can be doubted, though, that these eulogies are of interest outside the family circle.

Apart from writing a memory of her father, Anne might have something else in mind when she uses the pattern mentioned above: She probably modelled her family portrait on that of Anne Frank. Some parallels that are particularly obvious are Anne Jacob's precociousness and her arrogance when judging others. But this book is not at all full of intertexts; Anne never leaves us in doubt that she is not the bookish kind, and there is just one literary allusion: Anne compares her convent school to a Doll's house.

Like I have just said, Anne is making judgements all the time; on her family, but also on the political situation. She does the latter to keep a promise she made early in the book: To tell a story in which national occurrences have "personal repercussions" (21). However, she somewhat reverses her dictum, following this pattern: family incident(s) and what they teach us about the general situation in Germany. This is a good idea, only its execution is poor. To my mind, this is because of two things: Even the older Anne of Melbourne does not really know (or remember) that much about the situation in Germany in the 1920s and 1930. So (in addition to spelling mistakes) there are factual errors, both concerning the private and the public sphere, errors such as taking all German Protestants for Lutherans and describing the flag of the Weimar Republic wrongly. But what is worse is her naive textbook style when she tries to talk European politics to an Australian 
reader. Talking down is putting it mildly! She is also very condescending when she lectures about Germans:

... the majority of Germans were content, not knowing nor caring that their country was heading towards total autocracy. ... the millions who did not want liberalism, did not want to think for themselves and guide their own destinies, the millions who only wanted unity under a leader who would give them what they craved (173).

Anne's only excuse (was she aware of it?) is that even at a later stage in life she includes herself among those who do not want to think for themselves.

In keeping with Anne's naive look at life was her firm conviction as a child that nothing bad could happen to Jews in Germany because "German justice and German institutions were fair and incorruptible" (301). This attitude is at odds with references she makes of Jews being murdered. She knows better, but like a stubborn child refuses to believe it.

When it comes to politics, Anne of Melbourne probably tries to be fair to her younger self and presents facts but does not interpret them, since, like she says, she does (or did) not know enough. Her comment on a Hitler rally in Hannover is a case in point:

I do not know whether the things he said were the excited outpourings of a sincere fanatic or deliberate rhetoric, coldly calculated to rouse his audience to a fever pitch of unquestioning devotion. All I can remember, as I listened to the ranting blaring from the loudspeakers, was my surprise that his Austrian accent sounded so foreign to my north-German ears (158).

This continual schoolgirl attitude - affected or not - spoils Anne's book for me. 